Krzysztof Fedorowicz

Uniwersytet im. Adama Mickiewicza w Poznaniu

\title{
POZYCJA USTROJOWA PREZYDENTA W SYSTEMIE POLITYCZNYM ARMENII
}

\section{Wprowadzenie}

Upadek ZSRR w 1991 roku dla byłych republik stał się momentem przełomowym w ich historii. Na terytorium dotychczas w miarę spokojnym i ustabilizowanym pod względem polityczno-gospodarczym i społecznym, szybko pojawiły się oznaki destabilizacji i chaosu. Zainicjowane przemiany na tym obszarze miały charakter gwałtowny i nieoczekiwany, aby możliwe było świadome ich sterowanie i nadanie im ewolucyjnego charakteru według ustalonego wcześniej planu. Byłe republiki radzieckie, takie jak Armenia, już od pierwszych dni samodzielnego funkcjonowania na arenie międzynarodowej stanęły przed trudną oraz pilną koniecznością przeprowadzenia radykalnych reform politycznych, społecznych i gospodarczych.

Proces przejścia od realnego socjalizmu w stronę demokracji oznaczał dla Armenii początek długotrwałego etapu przejściowego, który niósł ze sobą szanse, ale także liczne zagrożenia. Odzyskanie po wielu latach suwerenności przez polityczne elity i społeczeństwo tej najmniejszej republiki radzieckiej było równoznaczne z fundamentalnymi przekształceniami w sferze kultury politycznej, od kształtu której miała zależeć jej siła, pozycja i międzynarodowa wiarygodność. W procesie kształtowania nowych rozwiązań ustrojowych w Armenii istotnym elementem stała się legitymizacja systemu politycznego, wyrażająca stopień akceptacji obowiązującego porządku polityczno-prawnego. Jednak rozwój stabilnego i odpowiednio funkcjonującego systemu politycznego wymaga sporego upływu czasu. Jak można zauważyć na przykładzie ewolucji zachodnich państw, proces przekształceń systemowych jest elementem długotrwałym, naznaczonym pojawiającymi się zaburzeniami i kryzysami. Często okazuje się, że łatwiej dokonać formalnej zmiany prawa, stosunków 
własności, aniżeli zmienić nabyte w ciągu kilkudziesięciu lat nawyki zachowania i myślenia wśród elit politycznych. ${ }^{1}$

W początkowym okresie kształtowania polityki wewnętrznej w Armenii priorytetową kwestią było zdefiniowanie pożądanego kształtu reżimu politycznego. ${ }^{2}$ Miało to duże znaczenie dla tempa, przebiegu i efektów zainicjowanych przekształceń ustrojowych. Jednak podejmowanie decyzji o kształcie tworzonych instytucji, sposobie ich przekształcania oraz egzekwowania ich za pośrednictwem władzy okazało się zadaniem trudnym. Próbowano kopiować strukturę i metody funkcjonowania organów państwowych w rozwiniętych państwach europejskich pomijając jednocześnie fakt, iż ich baza prawna kształtowała się w długim przedziale czasowym. Nieuwzględnienie w tej kwestii kaukaskiej specyfiki w „najlepszym” wariancie kończyło się przyjęciem aktów prawnych, których nawet nie próbowano realizować. ${ }^{3}$ Wśród elit politycznych nie było realnej gotowości, zdolności i chęci wykorzystania instytucji i mechanizmów prawnych w imię deklarowanych wartości. Tym samym ukształtowane na gruncie konstytucyjno-prawnym modelowe regulacje nie zawsze dowodziły świadectwa efektywności rozwiązywania problemów polityczno-społecznych. W miarę upływu czasu teoria i formalne rozwiązania prawno-ustrojowe coraz bardziej rozmijały się z polityczną rzeczywistością. ${ }^{4}$

Skomplikowane uwarunkowania wewnętrzne, tragiczna historia obfitująca w wydarzenia o charakterze przełomowym dla Ormian, stan faktycznej wojny z Azerbejdżanem w latach 1992-1994, praktyczna izolacja na arenie międzynarodowej i konieczność fizycznego przetrwania pierwszych lat niepodległości wywarły nieodwracalny wpływ na formowanie się modelu instytucjonalno-prawnego Armenii. Zróżnicowana struktura etniczna oraz wyznaniowa charakteryzująca państwa Kaukazu Południowego spowodowała natychmiastową eksplozję konfliktów etnicznych. To w połączeniu z brakiem demokratycznych tradycji w dużym stopniu uniemożliwiło przyswojenie na właściwym poziomie demokratycznych reguł gry i stało się przyczyną wyboru „bezpiecznej” i gwarantującej względną stabilność silnej prezydentury, która często posiada cechy tzw. miękkiego autorytaryzmu. W takich warunkach w kształtującym się systemie politycznym czynnikiem dominującym często

1 A. Wolff-Powęska, Oswojona rewolucja. Europa Środkowo-Wschodnia w procesie demokratyzacji, Poznań 1998, s. 49-52.

2 Pojęciem „reżim polityczny” w politologii określa się zależności charakteryzujące stosunki między władzą ustawodawczą a wykonawczą. To zespół wartości i norm odnoszących się do takich kwestii jak sposób powoływania egzekutywy, zakres jej współdziałania z legislatywą, wzajemne uprawnienia i odpowiedzialność elit politycznych. Reżim polityczny obejmuje swoim zakresem treściowym zasady, procedury i normy regulujące wzajemne stosunki między organami państwa, a także między instytucjami państwowymi a społeczeństwem. Szerzej: A. Antoszewski, R. Herbut, Systemy polityczne współczesnego świata, Gdańsk 2001, s. 309-310.

3 E. Minasyan, Armenia na ciernistym szlaku niepodległości, (w:) R. Czachor (red.), Armenia i Górski Karabach w procesach transformacji społecznej i politycznej, Wrocław 2014, s. 20.

4 А. Енгоян, Общность ценностных ориентации и ментальности постсоветских обществ, (w:) Г. А. Петросян (red.), Внешняя политика Республики Армения. Проблемы и вызовы, Ереван 2014, s. 55-58. 
stała się siła i przemoc, jako skuteczny i prosty mechanizm realizacji politycznych celów. ${ }^{5}$

Armenia jest typowym przykładem poradzieckiego państwa charakteryzującego się wyraźną dominacją ośrodka prezydenckiego. Elity władzy, po wstępnym okresie poszukiwań, zaakceptowały na czas nieokreślony specyficzny poradziecki reżim państwa „szarej strefy" $\mathrm{z}$ dominującą rolą partii rządzącej i ośrodka prezydenckiego. Do tej pory elity te nie wykazują dążeń do jego realnej zmiany czy istotnej modyfikacji z wyjątkiem działań mających wymiar medialno-propagandowy i służących realizacji politycznych profitów rządzącej elity.

Głównym celem publikacji jest analiza pozycji ustrojowej prezydenta w systemie politycznym Armenii, jego deklaratywnej i rzeczywistej roli, jaką pełni w ramach rozwiązań prawno-ustrojowych oraz kwestia jego wpływu na organy władzy ustawodawczej, wykonawczej i sądowniczej. Istotnym elementem jest także zakres konstytucyjnych uprawnień prezydenta, próby ich ograniczenia w wyniku presji społeczności międzynarodowej i pojawiające się ostatnio w Armenii tendencje do zmiany formy rządów z prezydencko-parlamentarnego na parlamentarny, jednak przy zachowaniu dotychczasowego stanu posiadania przez obecne elity.

\section{Pozycja ustrojowa prezydenta Armenii w latach 1991-2005}

Wzorem zdecydowanej części byłych republik ZSRR funkcję głowy państwa postanowiono powierzyć prezydentowi wybranemu w wyborach powszechnych i bezpośrednich. Wielopłaszczyznowe przeobrażenia systemu społeczno-politycznego i czas konfliktu zbrojnego o Górski Karabach na początku lat 90. XX w. wymagały sprawnie działającej egzekutywy. System prezydencki dawał nadzieję na osiągnięcie względnej stabilizacji w funkcjonowaniu państwa, przy jednoczesnym utrzymaniu demokratycznych pryncypiów. ${ }^{7}$ Już w czerwcu 1991 roku Rada Najwyższa podjęła decyzję o utworzeniu urzędu prezydenta. W dniu 1 sierpnia 1991 roku przyjęto ustawę O prezydencie Republiki Armenii, a dzień później O wyborach prezydenta Republiki Armenii. Pierwsze powszechne i bezpośrednie wybory

K. Fedorowicz, Rola siły i przemocy w kształtowaniu systemu politycznego Armenii, (w:), T. Bodio (red.), Kaukaz: mechanizmy legitymizacji i funkcjonowania elit politycznych, Tom VII, Warszawa 2012, s. 38-39.

6 Państwa należące do tej kategorii nie są dyktaturami, ale też nie zmierzają w swoich rozwiązaniach instytucjonalnych do rozwiązań przyjętych w państwach demokracji. Model politycznego ustroju w państwach tzw. „szarej strefy" charakteryzuje się dwiema tendencjami. W pierwszej, łagodniejszej, odbywają się regularnie wybory o względnej rywalizacyjności, co nie zawsze prowadzi do alternacji władzy. Dominują postawy zmierzające do ochrony interesów grup rządzących przy wysokim stopniu niechęci i dezaprobaty opinii publicznej wobec tzw. „świata polityki”. W drugiej, cechującej się wyraźnymi skłonnościami autorytarnymi, występuje ograniczanie przestrzeni politycznej, co najczęściej prowadzi do zdominowania sceny politycznej przez jedną tzw. partie władzy lub prezydenta i widocznym brakiem rywalizacyjności podczas wyborów, które często są fałszowane i nie spełniają wymogów demokratycznych. Szerzej patrz: W. Baluk, A. Czajowski, Ustroje polityczne krajów Wspólnoty Niepodległych Państw, Wrocław 2007, s. 8.

$7 \quad$ P. Sarnecki, Konstytucyjna pozycja prezydenta wybieranego przez parlament w państwach Europy Środkowo -Wschodniej, (w:) S. Bożyk (red.), Prawo, parlament i egzekutywa we współczesnych systemach rządów, Białystok 2009, s. 330. 
prezydenckie w Armenii odbyły się w październiku 1991 roku, a ich zwycięzcą został dotychczasowy przewodniczący parlamentu Lewon Ter-Petrosian, uzyskując poparcie ponad $83 \%$ głosujących. ${ }^{8}$

Wobec braku konstytucji parlament wydał przepisy regulujące podstawowe kwestie ustrojowe. Role najwyższego organu władzy państwowej miał pełnić parlament (Rada Najwyższa), a funkcje głowy państwa - prezydent. W tej sytuacji szczególnie istotnym zadaniem stało się jak najszybsze przygotowanie i uchwalenie nowej konstytucji, która kształtowałaby podstawowe zasady i wartości demokratycznego systemu rządów. W Radzie Najwyższej powstała komisja konstytucyjna, która w czerwcu 1993 roku wniosła do parlamentu projekt konstytucji zgodny z punktem widzenia ówczesnego prezydenta Lewona Ter-Petrosiana, który był zwolennikiem silnej prezydentury i słabego parlamentu. ${ }^{9}$ Projekt konstytucji został poddany przez prezydenta Lewona Ter-Petrosiana bezpośrednio pod referendum ogólnopaństwowe, które zostało przeprowadzone wraz $\mathrm{z}$ wyborami parlamentarnymi w dniu 5 lipca 1995 roku. ${ }^{10}$

Uchwalona w 1995 roku Konstytucja Armenii określiła podstawy ustroju politycznego Armenii, szczególnie w odniesieniu do struktury naczelnych władz państwa. Konstytucja wprowadziła do systemu politycznego elementy klasycznego parlamentaryzmu i systemu prezydenckiego, kształtujące model mieszanej formy rządów. W tym przypadku połączenie parlamentarnej formy rządów z modelem prezydenckim było wzorowane na doświadczeniach systemu semiprezydenckiego, $\mathrm{V}$ Republiki Francji.

Ustawa zasadnicza w sposób szczególny wyeksponowała stanowisko prezydenta republiki wybieranego w wyborach powszechnych na pięcioletnią kadencję. Został on uznany nie tylko za głowę państwa, ale też za gwaranta konstytucji oraz organ dominujący pod względem formalnoprawnym nad pozostałymi organami władzy. Był gwarantem harmonijnego funkcjonowania władzy ustawodawczej, wykonawczej oraz sądowniczej. Nie został usytuowany w ramach władzy wykonawczej, ale jako instytucja nadrzędna. ${ }^{11}$

Prezydent mógł nominować i odwoływać premiera według własnego uznania. Mimo wyodrębnienia funkcji premiera, to prezydent był rzeczywistym szefem rządu, przewodniczył posiedzeniom, a wszelkie podejmowane decyzje musiały być aprobowane przez niego. Premier mógł to robić jedynie z polecenia prezydenta lub

8 А. Э. Хачикян, История Армении, Ереван 2009, s. 219.

9 А. Маркаров, Реформа политических институтов в процессе демократического транзита в Армении,,Центральная Азия и Кавказ 2001”, nr 4 (16), s. 114-115.

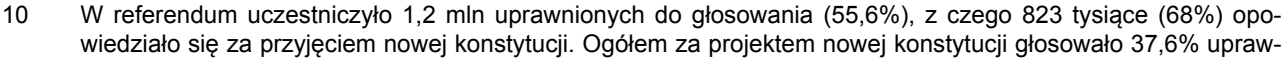
nionych do głosowania obywateli Armenii, co wskazuje na dość skromne poparcie ustawy zasadniczej wśród społeczeństwa, tym bardziej że warunkiem przyjęcia konstytucji w referendum był wymóg minimum $50 \%$ frekwencji i poparcie nie mniej niż 30\% uprawnionych do głosowania.

11 Первая Конституция Армении, http://www.parliament.am/legislation.php?sel=show\&ID=2425\&lang=rus (data dostępu: 22.09.2015 r.). 
w czasie jego choroby tylko na żądanie większości członków rządu. Oprócz prawa mianowania premiera i członków gabinetu, prezydent posiadał kompetencje do mianowania prokuratora generalnego i naczelnego wodza sił zbrojnych. Ponadto w jego gestii pozostawiono decydujący głos w kwestiach związanych z polityką zagraniczną, bezpieczeństwem państwa czy przeprowadzaniem reform gospodarczych. Prezydent dysponował także prawem do rozwiązania parlamentu i ogłoszenia przedterminowych wyborów bez istotnych powodów już po upływie roku od wyborów. Mógł to uczynić jedynie po konsultacjach z przewodniczącym parlamentu i premierem. ${ }^{12}$

Zgodnie z konstytucją prezydent był gwarantem niezawisłości organów sądowniczych i sprawował funkcję przewodniczącego Rady Sądownictwa Armenii. Przysługiwało mu prawo odwoływania sędziów, wyrażania zgody na ich aresztowanie i pociąganie do odpowiedzialności. Ponadto dość istotnym i niepokojącym faktem było to, że prezydent do momentu nowelizacji konstytucji w 2005 roku mógł w drodze dekretów i rozporządzeń z mocą ustawy (z czego często korzystał) regulować kwestie, które nie były unormowane. ${ }^{13}$ Ewidentnie zbyt daleko idące pełnomocnictwa prezydenta wobec wymiaru sprawiedliwości i rządu naruszały fundamentalną zasadę podziału władzy i stawiały pod znakiem zapytania efektywność wypełniania przez prezydenta obowiązków zapewnienia właściwego funkcjonowania władzy ustawodawczej, wykonawczej i sądowniczej. Ponadto pozycję prezydenta wzmacniał fakt, iż był on wybierany nie przez parlament, a przez naród w wyborach bezpośrednich. W systemie politycznym Armenii prezydent pełnił rolę superarbitra. ${ }^{14}$

Konsekwencją tak silnej pozycji prezydenta w systemie politycznym Armenii było znaczne osłabienie pozycji ustrojowej i roli parlamentu, który był organem ustawodawczym, posiadającym jednak wyraźnie ograniczone możliwości realizacji funkcji kontrolnej. W sytuacji posiadania przez prezydenta większości w parlamencie, praktycznie dysponował on nieograniczonymi pełnomocnictwami we wszystkich sferach władzy państwowej. W Armenii taka sytuacja miała miejsce w latach 1995-1997, kiedy to prezydent wyraźnie dominował w życiu politycznym, co w zasadzie oznaczało funkcjonowanie systemu superprezydenckiego. ${ }^{15}$

W latach dziewięćdziesiątych XX w. kształtowanie nowych instytucji i regulacji ustrojowych w Armenii często nie było równoznaczne z ich stosowaniem, egzekwowaniem i respektowaniem w życiu politycznym. Niektóre z tych rozwiązań przyjmowano nie $\mathrm{z}$ powodu postępującej demokratyzacji życia społecznego, co presji otoczenia międzynarodowego. Pierwsze lata obowiązywania konstytucji ujawniły jej niedoskonałość. W latach 1995-2005 przepisy konstytucji oraz praktyka prezy-

\footnotetext{
12 Ibidem.

13 A. Czajowski, Republika Armenii, (w:) W. Baluk, A. Czajowski (red.), Ustroje polityczne krajów Wspólnoty Niepodległych Państw, Wrocław 2007, s. 196.

14 R. Herbut, W. Baluk, Transformacja systemów politycznych państw obszaru byłego Związku Radzieckiego, Wrocław 2010, s. 62.

15 А. Маркаров, Реформа политических институтов..., op. cit., s. 117
} 
denta Lewona Ter-Petrosiana, jak i jego następcy, Roberta Koczariana sprawiły, że w Armenii, mimo formalnie istniejącego systemu semiprezydenckiego, w praktyce wykształcił się specyficzny model ustrojowy zbliżony do systemu superprezydenckiego, z głową państwa często wykraczającą poza swoje konstytucyjne uprawnienia. W wyniku specyficznego układu sił na scenie politycznej, parlament szybko stał się nieformalnym organem proprezydenckim. Niezbyt precyzyjne przepisy ustawy zasadniczej odnoszące się do kompetencji i uprawnień prezydenta, a także brak norm regulujących wiele dziedzin życia politycznego i społecznego szybko doprowadziły do potrzeby jej nowelizacji i dostosowania jej do wymogów współczesnej praktyki konstytucyjnej. Potrzeba zmiany konstytucji ujawniła się z całą mocą w związku ze staraniami władz Armenii o uzyskanie członkostwa w Radzie Europy.

\section{Nowelizacja konstytucji w 2005 roku - potrzeba zmian czy presja międzynarodowa?}

Rada Europy rekomendowała nowelizację konstytucji, wobec której zgłoszone zostały liczne zastrzeżenia, przede wszystkim związane z nadmiernymi uprawnieniami prezydenta oraz potrzebą dostosowania ustawodawstwa do wymogów organizacji w zakresie ochrony praw człowieka oraz gwarancji niezawisłości sądownictwa. Projekt daleko idącej nowelizacji konstytucji został poddany pod referendum w dniu 27 listopada 2005 roku. ${ }^{16}$ Wzięła w nim udział wymagana konstytucyjnie większość uprawnionych do głosowania, a za rewizją ustawy zasadniczej opowiedziało się ponad $94 \%$ głosujących.

W wyniku dokonanej nowelizacji konstytucji w systemie politycznym Armenii doszło do znacznego ograniczenia zakresu uprawnień prezydenta, który formalnie przestał być organem dominującym w strukturze aparatu państwowego. Nowe regulacje przede wszystkim bardzo istotnie umocniły pozycję ormiańskiego parlamentu i rządu, przyznając im szerszy zakres kompetencji. Tym samym wzajemne relacje między parlamentem a prezydentem i rządem oparte zostały na zasadach zbliżonych do modelu rządów parlamentarno-prezydenckich. Wzmocniona została pozycja parlamentu i przede wszystkim rządu wobec prezydenta. Obecnie parlament ma wyłączność ustawodawczą w wielu kwestiach, które zostały szczegółowo przedstawione w konstytucji. Prezydent utracił możliwość inicjatywy ustawodawczej, a kompetencje związane z wydawaniem dekretów z mocą ustawy zostały znacznie ograniczone. Wprawdzie prezydent nadal posiada możliwość rozwiązania parlamentu przed upły-

16 Warto zauważyć, że już w maju 2003 roku przeprowadzono referendum dotyczące nowelizacji konstytucji. Przygotowany pakiet zmian nie uzyskał jednak wystarczającego poparcia społecznego. Frekwencja wyniosła niecałe $52 \%$. Minimalna była różnica głosów „za” (559 687) w stosunku do przeciwnych (552 257) i wyniosła 7430 (poniżej 1\%). Znacząca była liczba głosów nieważnych, bo aż 98 tysięcy. Referendum nie zostało uznane za ważne, a władze zobowiązały się do przeprowadzenia w przyszłości kolejnego. Patrz: May 242003 Referendum (on Draft of Amendments to the Constitution of Republic Armenia, Central Electoral Commission Republic of Armenia, http://www.elections.am/resultsr2503/ (data dostępu: 30.08.2015 r.). 
wem kadencji, ale tylko w ściśle określonych przypadkach. Ponadto głowa państwa nie może już nominować i odwoływać premiera wedle swego uznania, jak to czynił wcześniej. Istotnym nowum jest zobowiązanie do konsultowania kandydatury premiera $\mathrm{z}$ większością parlamentarną oraz powołanie na ten urząd osoby, która cieszy się zaufaniem parlamentu. ${ }^{17}$ Przy podejmowaniu tej decyzji prezydent musi uwzględniać istniejący w danym momencie układ sił politycznych w Zgromadzeniu Narodowym. Wyłoniony w ten sposób rząd musi przedstawić parlamentowi do zaakceptowania program swojego działania. Przepis ten znacznie ogranicza możliwość wpływu prezydenta na personalną obsadę rządu, jednak w przypadku dysponowania przez głowę państwa silnym zapleczem parlamentarnym, taka możliwość nadal istnieje.

Ponadto nastąpiło istotne wzmocnienie pozycji premiera i rządu, który od 2005 roku ponosi odpowiedzialność polityczną wyłącznie przed parlamentem. Premier decyduje o składzie rządu, kieruje jego działalnością i przewodniczy posiedzeniom rządu. Wyjątkiem są posiedzenia rządu, na których rozpatrywane są zagadnienia z zakresu polityki zagranicznej, obronności i bezpieczeństwa państwa. Posiedzenia takie może zwoływać oraz im przewodniczyć także prezydent.

Po zmianach prezydent przestał być gwarantem obowiązującej konstytucji, a stanął na straży jej przestrzegania. Od 2005 roku także prezydent nie jest już gwarantem niezawisłości organów sądowych. W nowej konstytucji dokonano zmiany przepisów w systemie sądownictwa, a art. 91 znowelizowanej ustawy zasadniczej nie pozostawia w tym względzie żadnych wątpliwości, wskazując iż ,wymierzanie sprawiedliwości w republice Armenii należy tylko do sądów". ${ }^{18}$

Prezydent Armenii, podobnie jak głowa państwa w większości innych państw, nie ponosi odpowiedzialności politycznej przed parlamentem. Ponosi jednak odpowiedzialność konstytucyjną, a parlamentowi przysługuje prawo do wszczęcia procedury odsunięcia prezydenta Armenii od sprawowania urzędu. Art. 57 znowelizowanej konstytucji przewiduje, że Zgromadzenie Narodowe może skierować sprawę do Sądu Konstytucyjnego w przypadku, kiedy głowa państwa dopuści się zdrady stanu lub popełni inne ciężkie przestępstwo. Jeśli Sąd Konstytucyjny orzeknie o winie prezydenta, Zgromadzenie Narodowe może podjąć uchwałę o odsunięciu głowy państwa od sprawowania urzędu większością co najmniej 2/3 ogólnej liczby deputowanych.

Nowelizacja konstytucji Armenii w 2005 roku była postrzegana na arenie międzynarodowej jako dążenie władz tego kraju do liberalizacji życia społeczno -politycznego. Formalnie nastąpiło dość istotne osłabienie dotychczasowego prezydenckiego charakteru systemu politycznego, jednak praktyka ostatnich lat pokazała, że parlamentarno-prezydencki model władzy nie jest konsekwentnie wcielany w ży-

17 S. Bożyk, Zgromadzenie Narodowe. Parlament Armenii, Warszawa 2012, s. 13-14.

18 The Constitution of the Republic of Armenia, http://www.president.am/en/constitution/ (data dostępu: 30.08.2015 r.); S. Bożyk, System konstytucyjny Armenii, Warszawa 2012, s. 38-39, 60. 
cie. Pozycja prezydenta nadal jest silna, a istnienie dużej proprezydenckiej partii, dominującej w Zgromadzeniu Narodowym, znacznie osłabia pragmatyczny wymiar wprowadzonych zmian. Zostały one skutecznie zamortyzowane poprzez specyficzny system partyjny, w którym w zasadzie brak jest dużych i trwałych partii politycznych, zdolnych do efektywnej rywalizacji politycznej..$^{19} \mathrm{Od} 2003$ roku w ormiańskim Zgromadzeniu Narodowym i na scenie politycznej siłą dominującą jest proprezydencka Republikańska Partia Armenii, która skutecznie zapewnia prezydentowi poparcie polityczne i możliwość swobodnych manewrów na scenie politycznej, mimo znacznego ograniczenia jego kompetencji. Partia ta powstała w 1990 roku jako jedna z pierwszych partii politycznych w kraju. W parlamencie IV kadencji (w latach 2007-2012) spośród 131 deputowanych 63 było członkami parlamentarnej frakcji Republikańskiej Partii Armenii. Z kolei w Zgromadzeniu Narodowym V kadencji (2012-2017) proprezydencka partia posiada 70 deputowanych. ${ }^{20} \mathrm{O}$,,ponadstandardowej" symbiozie ośrodka prezydenckiego z dominującą partią w parlamencie może świadczyć fakt, że obecny prezydent Armenii Serż Sarkisian jest przewodniczącym Republikańskiej Partii Armenii. ${ }^{21}$

\section{Niestabilność systemu politycznego}

Nowelizacja konstytucji w 2005 roku związana z koniecznością dostosowania rozwiązań ustrojowych do wymogów Rady Europy, w wyniku której osłabiona została pozycja prezydenta w systemie władzy, stwarzała możliwość pozytywnych zmian w rzeczywistości politycznej Armenii. Tym bardziej, że elitom uzależnionym od międzynarodowej pomocy finansowej, zależało na polepszeniu wizerunku swego kraju i choćby częściowym wyodrębnieniu go z „szarej strefy” postradzieckich reżimów politycznych. Jednak wśród ormiańskich analityków pojawiły się opinie, iż referendum konstytucyjne było nie tylko wynikiem międzynarodowej presji, ale także hipotetycznego zagrożenia tzw. „kolorową rewolucją”. Wobec pojawiających się w najbliższym otoczeniu radykalnych przemian politycznych (tzw. „rewolucja róż” w 2003 roku w sąsiedniej Gruzji, ,pomarańczowa rewolucja” na Ukrainie w 2004 roku) władze postanowiły wobec państw zachodnich i własnego społeczeństwa okazać gotowość do demokratycznych zmian w postaci referendum w sprawie nowelizacji konstytucji, zmniejszenia uprawnień prezydenta i głębszego zdemokratyzowania mechanizmów politycznych w państwie. Wskazywano, iż nie odbyła się

19 R. Herbut, W. Baluk, Transformacja systemów politycznych..., op. cit., s. 63. www.parliament.am/deputies.php?sel=factions\&lang=rus (data dostępu: 30.08 .2015 r.). 21 The Republican Party of Armenia (Executive Body), http://www.hhk.am/en/executive-body/ (data dostępu:
31.08.2015 r.). 
publiczna dyskusja dotycząca proponowanych korekt w ustawie zasadniczej, a jej zmiana była jedynie medialnym działaniem na użytek międzynarodowej opinii. ${ }^{22}$

System polityczny Armenii w dalszym ciągu charakteryzuje się niestabilnością i podatnością na zaburzenia społeczno-polityczne, a prezydent, formalnie pozbawiony większości uprawnień, nadal dominuje w życiu politycznym. Po nowelizacji konstytucji w 2005 roku w Armenii kilkukrotnie miały miejsca poważne wstrząsy i demonstracje społeczeństwa niezadowolonego z braku realnych zmian, iluzji wprowadzonych rozwiązań konstytucyjnych, braku alternatywnych wyborów prezydenckich i parlamentarnych oraz pogarszających się warunków życiowych. ${ }^{23}$ Reakcją władz na coraz częstsze zaburzenia polityczne i manifestowanie przez obywateli swojego niezadowolenia jest prezydencki projekt reformy konstytucji Armenii i propozycja przekształcenia kraju w republikę parlamentarną po zakończeniu obecnej kadencji prezydenta w 2018 roku. ${ }^{24}$

Główną ideą proponowanych przez prezydenta zmian jest przeniesienie ciężaru władzy wykonawczej na premiera i rząd, przy równoczesnym mocnym ograniczeniu uprawnień głowy państwa. Prezydent będzie wybierany w wyborach pośrednich przez parlament i reprezentacje władz lokalnych na jedną siedmioletnią kadencję. Nie będzie już zwierzchnikiem sił zbrojnych (funkcję tę będzie pełnił premier), a także zostanie pozbawiony możliwości powoływania sędziów (co stanie się domeną parlamentu). Rola prezydenta zostanie ograniczona w zasadzie do

А. Искандарян, Армения в 2005 г.: конец постреволюционной эпохи, „Кавказ. Ежегодник Кавказского института СМИ", Ереван 2007, s. 8-10.

23 W przeprowadzonych 19 lutego 2008 roku wyborach prezydenckich już w pierwszej turze zwyciężył kandydat obozu władzy, premier Serż Sarkisian, uzyskując oficjalnie 52,82\% głosów. Jego rywal, lider opozycji Lewon Ter -Petrosian uzyskał 21,50 \% głosów i uznał wybory za sfałszowane. Ponad 100 tysięcy osób zgromadziło się 20 lutego 2008 roku na głównej ulicy Erywania i zażądało przeprowadzenia drugiej tury wyborów. 1 marca 2008 roku władze użyły siły i brutalnie spacyfikowały protesty. Zginęło 8 osób, a kilkadziesiąt zostało rannych (20 osób rannych podczas pacyfikacji zmarło później w szpitalach w wyniku odniesionych ciężkich ran i obrażeń). Kontrolę nad miastem przejęło wojsko, wprowadzono stan wyjątkowy i rozpoczęto represje wobec opozycji. Pacyfikacja protestów powyborczych sprawiła, że Armenia wkroczyła w najpoważniejszy w swojej współczesnej historii kryzys polityczny. Echa tych wydarzeń zdecydowanie mocno ugodziły w międzynarodowy wizerunek Armenii i znacznie pogorszyły postrzeganie tego państwa na arenie międzynarodowej. Społeczność międzynarodowa wyraziła duże zaniepokojenie głębokim kryzysem politycznym, w jakim się znalazła Armenia. Gwałtowna reakcja społeczności międzynarodowej sprawiła, iż wiosną 2011 roku podczas kolejnych wielotysięcznych manifestacji w Erywaniu władze nie odważyły się na ponowne użycie siły. Protesty organizowane były przez Ormiański Kongres Narodowy, na którego czele stał były prezydent, Lewon Ter-Petrosian. Domagano się ustąpienia prezydenta, rozpisania przedterminowych wyborów, uwolnienia więźniów politycznych, przestrzegania praw obywatelskich, a przede wszystkim ukarania winnych masakry opozycji w marcu 2008 roku. Skala tych protestów oraz obawa przed kolejną negatywną reakcją międzynarodową spowodowały, że obóz rządzący dość niespodziewanie zgodził się na rozmowy z opozycją, które jednak nie przyniosły satysfakcjonujących obie strony rezultatów, jednak wpłynęły na bardziej kompromisową postawę władz w kwestii dialogu społecznego. Nie używano siły i strony usiadły przy jednym stole, bez groźby aresztowania czy innych represji. Podobny mechanizm zadziałał podczas kolejnego politycznego przesilenia w czerwcu 2015 roku podczas kilkumiesięcznych manifestacji w centrum Erywania przeciwko podwyżce cen na energię elektryczną. Chociaż protesty miały podłoże czysto socjalne i nie były skierowane bezpośrednio przeciwko ormiańskim władzom, a rosyjskiemu koncernowi energetycznemu, to mimo dużej skali i intensywności, po raz kolejny władze nie zdecydowały się na otwartą konfrontację. Mimo podjętych negocjacji problemu nie rozwiązano, a jedynie odsunięto w czasie negatywne skutki podwyżki. Protesty po czasie straciły na rozmachu i ku zadowoleniu władz nie przybrały jednoznacznie politycznego charakteru. Л. Арутюнян, Конституционная реформа в Армении: путь к демократии или уловка властей, http://ru.rfi. fr/kavkaz/20150806-konstitutsionnaya-reforma-v-armenii-put-k-demokratii-ili-ulovka-vlastei (data dostępu: 2.09.2015 r.). 
funkcji reprezentacyjnej. Z kolei ster władzy wykonawczej przejmie premier, wybrany przez większość parlamentarną ${ }^{25}$. Natomiast Zgromadzenie Narodowe będzie wybierane tylko w systemie proporcjonalnym. ${ }^{26}$ Projekt znowelizowanej konstytucji został w sierpniu 2015 roku przez prezydenta Serża Sarkisiana przedłożony parlamentowi ${ }^{27}$, a w dniu 6 grudnia 2015 roku odbyło się referendum konstytucyjne, w którym udział wzięło 50,5\% uprawnionych do głosowania, z których $63,3 \%$ opowiedziało się za nowelizacją konstytucji ${ }^{28}$. Część ormiańskiej opozycji wskazuje jednak, że proponowane zmiany doprowadzą do jeszcze większego stanu posiadania w parlamencie reprezentacji proprezydenckiej Republikańskiej Partii Armenii, a Serż Sarkisian jako przywódca tej partii po zakończeniu drugiej kadencji na stanowisku prezydenta może zostać wybrany premierem i będzie miał praktycznie nieograniczoną władzę. Warto zauważyć, iż na obszarze poradzieckim taka sytuacja miała już miejsce w Mołdawii w latach 2001-2009, która będąc formalnie republiką parlamentarną była de facto zdominowana przez prezydenta Władimira Woronina. ${ }^{29}$ Wyniki referendum dają słaby mandat znowelizowanej konstytucji, która zamiast dokonać rzeczywistej zmiany systemu politycznego Armenii, najprawdopodobniej w dużej mierze przyczyni się do jeszcze większej konsolidacji dotychczasowego obozu władzy, ograniczenia działania opozycji parlamentarnej oraz pogłębienia społecznej apatii wobec braku możliwości decydowania o losach własnego kraju.

\section{Podsumowanie}

Cechą charakterystyczną systemu politycznego Armenii jest świadomy wybór i kształtowanie nieformalnego układu zależności personalnych, których głównym centrum jest prezydent, bez względu na jego formalną pozycje i konstytucyjne

А. Чилингарян, Проект принят: Слово за народом, „Голос Армении”, nr 104, 6.10.2015.

Obecnie w okręgach jednomandatowych wybieranych jest 41 deputowanych, natomiast pozostałych 90 wybieranych jest w wyborach proporcjonalnych w jednym okręgu ogólnokrajowym.

Проект конституционных реформ направлен в парламент Армении, http://www.vestikavkaza.ru/news/Proekt-konstitutsionnykh-reform-napravlen-v-parlament-Armenii.html (data dostępu: 2.09 .2015 r.).

8 W głosowaniu udział wzięło około 1,3 mln Ormian, z których 825 tysięcy głosowało za, a 421 tysięcy przeciwko nowelizacji konstytucji. Zwraca uwagę duża liczba głosów na „nie” w Erywaniu i Gyumri, gdzie odbywały się nieliczne protesty przeciwko zmianie konstytucji. Szerzej patrz: Referendum on amendments to the Constitution of the Republic of Armenia, December 06, 2015 Referendum, Central Electoral Commission Republic of Armenia, http://www.elections.am/referendum/election-26015/ (data dostępu: 4.01.2016 r.).

W lipcu 2000 roku mołdawski parlament dokonał zmian w konstytucji i przekształcił Mołdawię w republikę parlamentarną. Zwiększone zostały kompetencje rządu przy równoczesnym zmniejszeniu prerogatyw prezydenta, który od tej pory jest wybierany przez parlament. Jednak parlamentarna forma rządów w Mołdawii nie doprowadziła do całkowitej marginalizacji prezydenta. W wyniku wyborów parlamentarnych w 2001 roku doszło do obsadzenia wszystkich stanowisk w państwie przez przedstawicieli Komunistycznej Partii Republiki Mołdawii. Lider tej partii, Władimir Woronin, wybrany przez parlament na prezydenta, szybko rozpoczął proces zawłaszczania państwa. Uzależnił od siebie pozostałe ośrodki władzy państwowej, a swoje prerogatywy realizował z naruszeniem norm konstytucyjnych. Tym samym ukształtował się niebezpieczny precedens wykraczania poza swoje uprawnienia przez prezydenta, który stał się osobą rządzącą republiką parlamentarną. Szerzej patrz: K. Fedorowicz, System rządów parlamentarnych na obszarze poradzieckim. Casus Mołdawii i Łotwy, „Przegląd Politologiczny” 2012, nr 2, s. 124-126; T. Kapuśniak, M. Słowikowski, Mołdawia - rara avis in terris? Charakterystyka mołdawskiego reżimu politycznego na tle poradzieckich doświadczeń transformacyjnych, Lublin-Łódź 2009, s. 32-33. 
uprawnienia. Jako głowa państwa stoi na czele kraju i tworzy równoległą do państwowych instytucji nieformalną strukturę, która realnie administruje krajem. Następuje to kosztem odrzucenia sprawdzonych i wypróbowanych metod budowy instytucjonalnych struktur państwa. Podjęta próba budowy demokracji parlamentarnej w Armenii uwarunkowana jest też swoistą specyfiką kultury elit politycznych. Jako reakcja na osłabienie i niewydolność funkcji opiekuńczych państwa w pierwszej połowie lat 90. XX wieku, doszło do wzmocnienia i tak tradycyjnie silnych na Kaukazie Południowym więzi klanowych. Klanowy protekcjonizm, w społeczeństwach zachodnich postrzegany jako zjawisko korupcyjne, w ogólnej świadomości społeczeństwa ormiańskiego jest naturalnym i właściwym świadectwem lojalności. Mimo formalnego ograniczenia uprawnień prezydenta Armenii, w dalszym ciągu jest instytucją dominującą w życiu politycznym kraju.

Armenia po dwudziestu pięciu latach niepodległości znajduje się na początku drogi do zaakceptowania mechanizmów demokratycznych w życiu politycznym. Podobnie jak część państw b. ZSRR (Mołdawia, Gruzja), próbuje wyjść z grupy państw tzw. ,szarej strefy” i ukształtować zbliżony do modelu parlamentarnego system polityczny. Mają temu służyć przeprowadzane nowelizacje konstytucji i ograniczanie uprawnień głowy państwa. Jednak mechanizmy, zasady, procedury i normy regulujące wzajemne stosunki między władzą ustawodawczą a wykonawczą charakterystyczne dla reżimów politycznych państw demokracji nieskonsolidowanej, nadal są postrzegane w Armenii symbolicznie, w sposób nie przystający do rzeczywistości. Często przyczyną ich wprowadzania jest presja społeczności międzynarodowej i chęć zaprezentowania gotowości do ewentualnych zmian w celu osiągnięcia krótkoterminowych politycznych profitów. Zbyt duży jest jeszcze rozdźwięk między rozwiązaniami formalnoprawnymi a realiami życia społeczno-politycznego.

\section{BIBLIOGRAFIA}

Antoszewski Andrzej, Herbut Ryszard. 2001. Systemy polityczne współczesnego świata. Gdańsk: Wydawnictwo Arche.

Baluk Walenty, Czajowski Andrzej. 2007. Ustroje polityczne krajów Wspólnoty Niepodległych Państw. Wrocław: Wydawnictwo Uniwersytetu Wrocławskiego.

Bożyk Stanisław. 2012. System konstytucyjny Armenii. Warszawa: Wydawnictwo Sejmowe.

Bożyk Stanisław. 2012. Zgromadzenie Narodowe. Parlament Armenii. Warszawa: Wydawnictwo Sejmowe.

Czajowski Andrzej. 2007. Republika Armenii. W Ustroje polityczne krajów Wspólnoty Niepodległych Państw, 196. Wydawnictwo Uniwersytetu Wrocławskiego.

Енгоян Ашот. 2014. Общность ценностных ориентации и ментальности постсоветских обществ. W Внешняя политика Республики Армения. Проблемы и вызовы, 55-58. Ереван, Издательство ЕГУ. 
Fedorowicz Krzysztof. 2012. Rola siły i przemocy w kształtowaniu systemu politycznego Armenii. W Kaukaz: mechanizmy legitymizacji i funkcjonowania elit politycznych, Tom VII, 38-39. Warszawa. Wydawnictwo Aspra-JR.Wydawnictwo Aspra-JR. Fedorowicz Krzysztof. 2012. „System rządów parlamentarnych na obszarze poradzieckim. Casus Mołdawii i Łotwy”. Przegląd Politologiczny 2: 124-126.

Хачикян Ашот. 2009. История Армении. Ереван.

Искандарян Александр. 2007. „Армения в 2005 г.: конец постреволюционной эпохи”. Кавказ. Ежегодник Кавказского института СМИ: 8-10.

Kapuśniak Tomasz, Słowikowski Michał. 2009. Mołdawia - rara avis in terris? Charakterystyka mołdawskiego reżimu politycznego na tle poradzieckich doświadczeń transformacyjnych. Lublin -Łódź: Wydawnictwo Instytutu Europy Środkowo-Wschodniej.

Маркаров Александр. 2001. „Реформа политических институтов в процессе демократического транзита в Армении". Центральная Азия и Кавказ 4 (16): 110-113.

Minasyan Edik. 2014. Armenia na ciernistym szlaku niepodległości. W Armenia i Górski Karabach w procesach transformacji społecznej i politycznej, 20-21. Wrocław. Instytut Polsko-Rosyjski.

Sarnecki Paweł. 2009. Konstytucyjna pozycja prezydenta wybieranego przez parlament w państwach Europy Środkowo-Wschodniej. W Prawo, parlament i egzekutywa we współczesnych systemach rządów, 330-331. Białystok. Temida 2.

Wolff-Powęska Anna. 1998. Oswojona rewolucja. Europa Środkowo-Wschodnia w procesie demokratyzacji. Poznań: Instytut Zachodni. 


\section{THE POSITION OF THE PRESIDENT} IN THE POLITICAL SYSTEM OF ARMENIA

The Author analyzes the role and position of the president of Armenia's political system. It indicates excessive powers and competence of the head of state to other centers of power. The president of Armenia, in spite of competence in 2005, is still the dominant authority in the political system. Democratization of the political system is the only apparent change. Changing the constitution will not lead to an actual reduction in the powers of the head of state.

Keywords: political system, president in the political system, Armenia, presidential system, semi-presidential system

Słowa kluczowe: system polityczny, prezydent w systemie politycznym, Armenia, system prezydencki, system semi-prezydencki 